\section{Seeing the wood for the trees}

Norman Myers

The Purpose of Forests: Follies of Development. By J. Westoby. Basil Blackwell: 1987. Pp. 343. £35, \$60.

TROPICAL forests are falling; we all know that. Yet it is simplistic to blame the feller of the forests, whether commercial logger or subsistence peasant. Both act in response to economic and social forces which they may only dimly discern, let alone understand. So to point an accusing finger at the man with the chainsaw or machete is to aim at the symptoms of the problems, rather than the problems themselves.

But today the problems have grown so pervasive and profound that it may even be of little use to tackle them any more. Rather we should address their sources. Within most tropical-forest countries, these sources include development strategies gone wrong, economic inequalities, oligarchical governments, absurdly inefficient administrations and the Cinderella status of forestry departments.

In the Philippines, until just a couple of years ago, more than half of all logs

\section{THE
MANAGEMENT OF AIDS PATIENTS}

Edited by DAVID MILLER,

\section{JONATHAN WEBER and JOHN GREEN}

The Management of AIDS Patients is the

first comprehensive guide to the practical clinical management of patients with AIDS or HTLV III infections. The book avoids the sensational aspects of the disease, offering solid advice and information for all people involved in patient care.

The editors and many of the contributors come from St Mary's Hospital, London one of the foremost centres in Britain for the treatment of AIDS patients. The knowledge and experience of these experts has been combined to provide a much-needed book for doctors, nurses, dentists and indeed for health-care professionals everywhere.

$$
1986
$$

$200 \mathrm{pp} \quad$ Hardback $\quad 0333404653 \quad £ 30.00$ 200pp Paperback $0333404661 \quad £ 12.95$ Please order this title from your bookseller - or in case of difficulty from Felicity Davie, Macmillan Press, Houndmills, Basingstoke, Hants RG21 2XS.

\section{MACMILLAN}

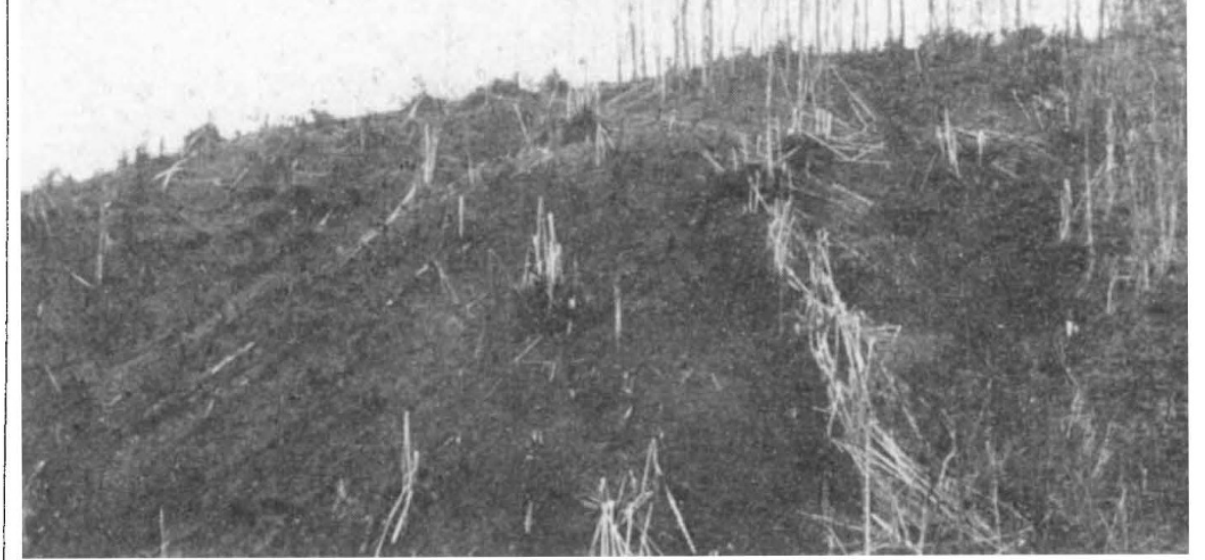

Visible symptoms - deforestation of the South Thailand hillsides.

exported were "poached" by cronies of former president Marcos. Similar timber rustling is common in Thailand. In Madagascar, the parlous state of the economy has been further aggravated by debt burdens, closing off prospects of making agriculture more intensive in traditional farmlands - this being the soundest way to reduce the "push" motivation for impoverished peasants to migrate towards the remaining forests. In Brazil, the best strategy to safeguard Amazonia is not to build a fence around it in order to keep out throngs of landless settlers. It is to engage in agrarian reform in southern Brazil, with its major agricultural lands, a region which could accommodate twice as many farmers as there are now in the whole country.

These are the sorts of insights proclaimed by Jack Westoby. The 16 lectures and papers that make up this book reflect the evolution of his views since the early 1960 s, when he was rising towards the upper echelons of the UN's Food and Agriculture Organization's Forestry Department. In those far-back days it was supposed that tropical forests were little more than so many board-feet of timber; the approach was "How can we best exploit the forests?". By the 1970s a new view became current, to the effect that the forests contribute not only material goods but environmental services as well, notably in their role as watersheds. So the approach changed to "How can we best develop forests?", even if that sometimes meant leaving them standing. By the 1980 s there was a further shift to "How can we enable forests to make their full contribution to development overall?" that is, how can they best add to a nation's gross national product?

Yet even this last approach, enlightened as it is when compared with earlier times, misses the point. As Westoby demonstrates in a dozen graphic ways, forestry is not primarily about trees, it is about people. It concerns trees only insofar as they serve the legitimate needs of people - especially the multitudes of halfdestitute people who share the rural habitats of forests. If these people do not perceive forests as sustaining their welfare, they will take a matchbox to them. Unless this central premise is accepted, there will soon be no tropical forests left for foresters - or conservationists - to agonize over

Telling professional foresters that they should be concerned about local villagers as well as trees has not always endeared Westoby to his more traditionalist colleagues. When he presented a keynote address at the World Forestry Congress in Jakarta, and took to task the assembled thousands for misperceiving their mission, he caused many an eyebrow to be raised in askance. But it is one of the strengths of this book that Westoby is always briskly straightforward. Thus we find the substance is set out with fierce conviction. And he always presents his acerbic message with genial goodwill: he takes his subject seriously, himself much less so.

By the time I joined FAO's Forestry Department, Westoby had retired, and for all I knew his message had been quietly filed away in the archives. So I especially welcome this book, and I am sure I shall return to it many a time for inspiration as well as instruction. There is little in it about cutting rotations, species provenances, wood chemistry and other technical matters. But there is much in it to commend to the development expert, resource economist, land-use planner, academic, conservationist - and the forester who recognizes the radically changed nature of the world in which he pursues his profession.

Norman Myers, Upper Meadow, Old Road, Headington, Oxford $O X 38 S Z$, UK, is a consultant on development and environmental matters. 